\title{
2000年の節目にあたり思うこと \\ Expectations for Midwifery Practice in the Year 2000
}

\author{
若 松 かをい (Kaoi WAKAMATSU)* \\ 第14回日本助産学会学術集会会長
}

ミレニアムの始まり, 激動の年, 少子の新世 紀, 昨年の出生数は過去最低の 117 万 5 千人…千 年紀のべビー出生への産み控えでは…また今年の 推定人口の $51 \%$ が女性, うち半分以上を 40 歳以上 の中高年女性が...少子・高龄化傾向の記事の中, 変革の時代を見据え, 発想の転換と業務の見直し …質の充実, 新分野の確保, 拡大・開拓, そし て, 関係職種との密な連携が求められる中, 実践 にあたっては, 下記の内容などの再確認の必要性 を常に感じております。

1. 助産業務遂行上の確認 (ズレの修正面)

(1) 助産婦教育課程 (1971，1990，1997年)。 能力, 役割拡大を踏まえて, 3 回の改正。 特に特性は生殖への対応, 地域母子保健導入, 母性各期をマタニティサイクル，ライフサイク ルの観点から，女性の生涯を通しての性と生殖 の健康過程への対応…新概念の導入など。

(2) 就業助産婦数の実態 ( 2 年ごとに報告)。

2. 重要な報告書類の確認（時代の先取り）

(1) 日本助産学会 (1998年12月), 将来の助産婦 のあり方委員会報告「日本の助産婦が持つべき 実践能力と責任範囲」。(詳細に記述)

(2) ICM, 基本的助産業務に必須な能力。1999 年 5 月, 第25回 ICM マニラ大会で採択。助産 婦業務の範囲…1992年, ICM $/ \mathrm{WHO} / \mathrm{FIGO}$ …助産婦の定義を基に構築。

(3) ヘルスプロモーションの概念（1986年, WHO 提唱)。健康 $\cdots$ 各人の自助努力で, 今ま での保健指導型から, 自己学習の援助型へ。

3. 母子保健政策の現状把握と確認事項 （1997年，住民に密着した市町村へ移管）

(1) 今後の子育て支援のための施策の基本的方向 について (エンゼルプラン)。1995年（少子化 への施策‥10 年間実施を目途に)。※「健やか
親子 $21 」$, 目標年次 2010 年, 策定中。

(2) 生涯を通じた女性の健康支援事業

（1996年12月，厚生省児童家庭局母子保健課）。 「男女共同参加 2000 年プラン」の基本的考え方 と行動計画として，上記の中にリプロダクティ ブ・ヘルス/ライツの新概念を導入し，施策の 基本的方向と具体策が打ち出された。

(3) 母性, 乳幼児に対する健康診査及び保健指導 に関する実施要領（1997年，30年目の改正）。

*

以上，事前準備上把握したい情報を一応表題の み記述したが, 特に助産婦教育面は入学年度とも 関連して, 再確認の必要があるのではと思います。 今後の課題として, 今までの業務遂行上不十分 ではと思われる一部を，市町村で計画中の母子保 健政策も踏まえて考えてみたい。

(1) マタニティサイクルの観点から（業務の充 実・発展面。助産婦の $83 \%$ 方病産院へ勤務)。実 習先の保健婦の声…周産期領域は, 病院の責任 範囲ですからと…女性の生涯の健康面も育児支 援も原点の時期に関与している。

質, 継続面から役割を果たしているのだろうか。 (2) ライフサイクルの観点から（活動分野の確 保, 開拓面)。性教育 (保護者, 成人期の未婚 男女)，授乳期以降～更年期前後の女性

(3) 関係者（保・助・看・他）との連携と協働の あり方では, 例, 市町村保健婦と密な連携の 下, 研修計画の中に, 助産の専門領域からの項 目を組み込んでもらって実施する（相手方から の依頼と自助努力), その他 (模索)。

(4) 展開場所は, 施設外…市町村保健センター, 保健所, 助産所, 学校教育の場, 他。

実現に向けては, 専門領域からの自己研鑽は必 須と思います。

* 鹿児島純心女子大学看護学部 (Kagoshima Immaculate Heart University, School of Nursing) 